
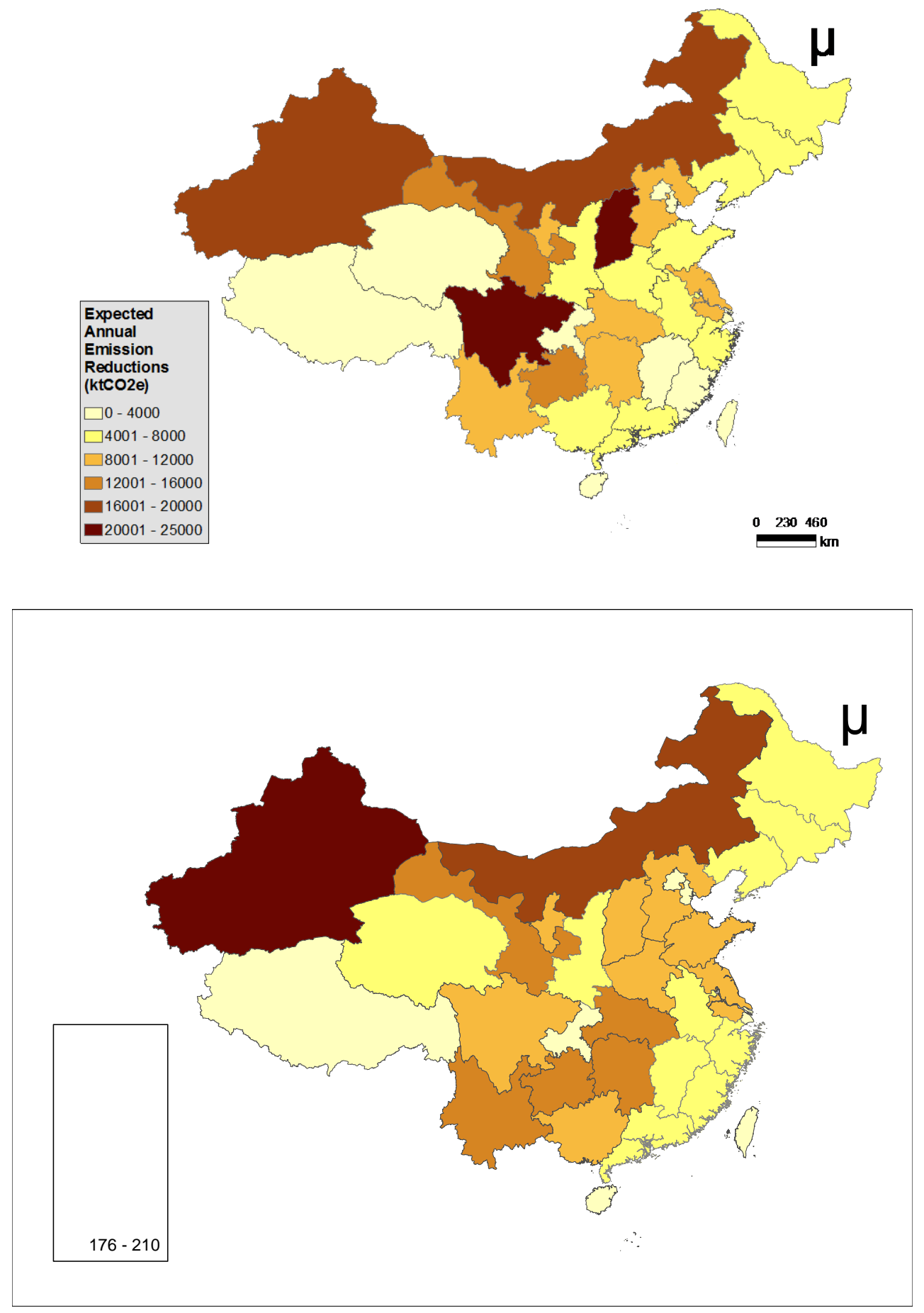


\section{After CDM: domestic carbon offsetting in China}

Alex Y. Lo

Ren Cong

Department of Geography, University of Hong Kong, Hong Kong

\section{Citation:}

Lo, A.Y. and Cong, Ren (2017) After CDM: domestic carbon offsetting in China. Journal of Cleaner Production. 141, p. 1391-1399. DOI:

http://dx.doi.org/ 10.1016/j.jclepro.2016.09.220

Publisher version available from authors: alexloyh@hku.hk 


\begin{abstract}
A domestic alternative to the Clean Development Mechanism (CDM) is operating in China, creating new opportunities for offsetting greenhouse gas emissions. More than two thousands 'Chinese Certified Emission Reduction' (CCER) projects have been validated. The state-led programme is important as it represents a transition of China's carbon market from specializing in the export of emission reductions toward serving domestic consumption. This article provides a snapshot of the 'post-CDM' context in China. It explores whether the CCER programme reveals a general pattern of development that is different from that of the CDM. Official project records are used to show the geographical and sectoral distribution of CCER projects. These records suggest that the western and northern areas of China will continue to play a key role in generating emission reductions, if not a stronger one than in the CDM. The shift toward inland may create development benefits. Sectoral distribution is a potential source of variations from the CDM. While the majority of emission reductions will be derived from renewable energy sources, a significant minority will come from waste-based ones. The market has expressed an interest in the re-use of biogas in rural areas. These initial observations could inform policy discussions and help forecast the potential share of key provinces and sectors in the new carbon market.
\end{abstract}

Keywords

Carbon offset; emission reduction; carbon market; climate change; China; CDM 


\section{Introduction}

The Clean Development Mechanism (CDM) is one of the Flexible Mechanisms defined in the Kyoto Protocol. Since 2005, it has enabled emission-reduction projects in developing countries to earn certified emission reduction (CER) credits, each equivalent to one tonne of $\mathrm{CO}_{2}$. These credits are transferrable and can be traded in the markets. Industrialized countries can acquire and use CERs to a meet a part of their emission reduction targets under the Kyoto Protocol. By the end of December 2015, a total of $1,642 \mathrm{MtCERs}$, arising from 2,864 emission-reduction projects, have been issued by the CDM Executive Board (EB). The number of registered CDM projects has reached 7,684.

China has been the world's largest producer and exporter of CER credits (Bayer et al., 2013; Thomas et al., 2011). Most of these credits are generated from renewable energy projects, notably hydroelectricity and wind power. However, the deterioration of CER prices since 2010 and consequently the sharp decline in returns have discouraged participation by Chinese project owners and developers. As the prospects for CER export become uncertain, China has embarked on a transition toward domestic market mechanisms for GHG mitigation.

The Chinese central government has introduced several initiatives since late 2011. One notable example is the pilot emission trading schemes (ETS) currently operating in selected Chinese provinces and cities, and the national ETS in the pipeline (Lo and Howes, 2013; Lo and Howes, 2015; Shen, 2015; Wu et al., 2014; Zhang, 2015a, b). These schemes constitute an 'allowance-based' market, from which polluting entities acquire emission allowances mainly for compliance purposes. Another form of emerging carbon market in China is 'project-based' market, which involves the production and trading of carbon emissions offsets. Carbon offsets allow polluting entities to fulfil their voluntary commitments and, in some jurisdictions, meet regulatory requirements. Over the years the project-based CDM market in China has received considerable attention. Yet, limited efforts have been made to understand the emerging Chinese Certified

Emission Reduction (CCER) market, which can be seen as a domestic alternative to the declining CDM and has come into operation only recently.

This study improves the current understanding about the CCER market by making a comparison with CDM projects hosted by China. It addresses the question that whether or not the CCER programme reveals a general pattern of development that is different from that of the CDM. We focus on the variations in project location and project category. Project location is an important factor to examine, because previous 
studies have demonstrated systematic tendencies in geographical distribution. Bayer et al. (2013), for example, have shown that Chinese CDM projects are concentrated in provinces of high electricity consumption, low per capita income, and lacking foreign direct investment. Project category is also worth exploring as studies have found a sectoral preference within China for CDM projects in "identified priority areas", such as energy efficiency, renewable energy, and methane recovery and use (Buhr et al., 2012, p. 85). These perspectives suggest that the CDM in China is leveraged to address national development goals (Bayer et al., 2013; Lo, 2015; Schröder, 2011; Teng and Zhang, 2010; Thomas et al., 2011; Wang and Chen, 2010). Project location and category are explicit indicators of the strategies being deployed for this purpose. For instance, promoting CCER in the poorer south-western part of China could support local development and the policy goal of poverty alleviation, and financing renewable energy projects could benefit the policy goal of strengthening energy security. Our inquiry into the location and category of CCER projects can shed light on the extent to which such geographical and sectoral tendencies continue to exist as the CDM no longer plays a central role in China's carbon market.

The remainder of this article presents an overview of validated CCER projects. It is based on the public records of these projects solicited from an official database maintained by a central government agency. By outlining the shape of the emerging project-based market, this paper seeks to capture the patterns of change and inform the discussions on China's climate and energy policies currently in transition toward a market-based approach. The present attempt in mapping out the post-CDM context can provide market participants, new energy developers, and researchers some idea about the potential market share of key provinces and sectors. It can also illuminate the ways forward as a national ETS is expected to be implemented in or after 2017, which has come to the forefront of international focus and will create enormous demand for domestic carbon offsets.

\section{Policy background}

In China, the use of domestic offsets for fulfilling compliance obligation is permitted. More than two thousands Chinese enterprises are included in seven pilot ETSs (Shanghai Environment and Carbon Exchange, 2016), which are operating in five major cities (Beijing, Tianjin, Shanghai, Shenzhen, and Chongqing) and two provinces (Guangdong and Hubei) (see Table 1 for their GDP and populate estimates, along with all other 
Chinese provinces ${ }^{1}$ ). Governments of the seven cities and provinces determine the level of local emissions caps, set up their trading rules, and issue emissions allowances to entreprises within their jurisdictions. Carbon exchanges have been set up in each of the pilot ETS sites. A total of 118.1 million tonnes of $\mathrm{CO}_{2}$-equivalent have been traded since 2013, when the first ETS was launched in Shenzhen. Trading prices range from US\$1.7 to US\$5.7 per tonne of $\mathrm{CO}_{2}$-equivalent (Table 2). Guangdong and Hubei Provinces have the most active carbon markets in China in terms of accumulated trading volume, while Shenzhen and Beijing have recorded higher prices than in the other five domestic markets.

The CCER programme gained a clearer shape in 2012. The regulatory conditions for producing domestic carbon offsets (i.e. CCER credits) were formally specified in the "Interim Measures for the Administration of Voluntary Greenhouse Gas Emission Reduction Trading" released by the National Development and Reform Commission (NDRC) (National Development and Reform Commission, 2012). The CCER programme resembles the CDM in many aspects. Proposed CCER projects must adopt methodologies approved by the NDRC, which are, to a large extent, built upon those of the CDM. Six GHGs are covered, namely $\mathrm{CO}_{2}, \mathrm{CH}_{4}, \mathrm{~N}_{2} \mathrm{O}, \mathrm{HFCs}, \mathrm{PFCs}$, and $\mathrm{SF}_{6}$. Third-party validation and verification are required. Project developers have to demonstrate additionality and potential sustainability benefits before a project is approved and registered with the NDRC. The key document for assessing requests for registration and validating a project activity is the CCER Project Design Document (PDD). Project developers have to submit their applications via the local Development and Reform Commission (DRC) or the NDRC. Project location is not limited to the seven pilot ETS sites.

CCERs have been traded and used for compliance since January 2015, when the Voluntary Greenhouse Gas Emission Reduction Trading Registry began operation. Information about CCER prices and trading volumes remains fragmented. According to the Shanghai Environment and Carbon Exchange (2016), the first transaction was recorded in Guangdong Province in March 2015. A total of 68.7million tonnes of $\mathrm{CO}_{2}-$ equivalent have been traded in six of the seven ETS locations (there is no information on Chongqing) (Table 2). Shanghai accounts for 36.7 per cent of the total trading volumes, playing a key role in the CCER market. CCERs were traded at an average price of US\$2.5 in Beijing and US\$3.7 in Shanghai.

\footnotetext{
${ }^{1}$ For the purpose of this article, provinces also refer to the four directly administrated municipalities (Beijing, Shanghai, Tianjin, and Chongqing) and autonomous regions.
} 
A possible reason for Shanghai's dominating CCER market share is that there are fewer restrictions on the use of offsets for compliance with the requirements of the Shanghai ETS (Shanghai Environment and Carbon Exchange, 2016). In fact, the conditions for the use of offsets vary across schemes. Although CCERs can be used for compliance in the pilot ETSs, the majority of them are location-specific and restricted to the compliance market of the region in which the CCER project is located (World Bank, 2015). All CCERs to be used for compliance with the Hubei ETS have to be locally produced in the province, but those for the Shenzhen ETS have to be generated from outside the city. CCERs generated in Beijing cannot be used to offset emissions from certain facilities or sectors (Zhang, 2015a). Regulated entreprises in Beijing and Shanghai can use CCERs to fulfil no more than 5 per cent of the compliance obligation, whereas Chongqing permits a maximum of 8 per cent and the other four locations accept a more generous limit of 10 per cent (Table 2).

Although restrictions vary across provinces and cities, the prospective national ETS is likely to cover the entire country and establish rules and requirements that are applicable to all local areas of China. The grand scheme is also likely to bring a sharp increase in demand for CCERs and create new opportunities for offsets trading. As the CCER market is expected to grow even more rapidly when the national ETS is implemented, it has high potential for altering the incentive structures and reconfiguring institutional setups that shape the production and consumption of energy. The following sections provide an overview of this burgeoning offset market.

\section{Methods}

We focus on the types and distribution of CCER projects across the country. Primary data were collected from the official website of the CCER programme, which is known as 'China Certified Emission Reduction Exchange Info-Platform' (cdm.ccchina.gov.cn/ccer.aspx) (hereafter, 'CCER Platform') and run by the NDRC's Department of Climate Change (qì hòu sī). A total of 2,296 CCER projects have been validated by approved third-party institutions (as of 9 August 2016) and their PDDs are openly available from the CCER Platform. Our sample includes these PDDs, but not those of the registered projects because there were less than 800 entries on the CCER Platform by the time we collected the data, which did not offer a solid statistical basis for comparing with CDM projects. Two CCER projects were subsequently excluded due to duplication, leaving 2,294 PDDs in the final sample. 
We made use of three sets of original data from the PDDs. The first one is the location in which the CCER projects operate, i.e. the provinces from which emission reductions will be generated. Two projects span over two provinces; their location codes were therefore assigned according to the project owners' registered addresses. Second, we recorded the expected annual emission reductions from each project during the first crediting period (nonetheless, there may be updates in records upon registration with the NDRC).

The third set of information is methodology codes, which are used to assign project types. All CCER projects were presented in the PDDs with a Chinese methodology code beginning with 'CM', 'CMS' or 'AR'. The Chinese codes were recorded and converted into their CDM equivalents according to an official list of approved methodologies published on the CCER Exchange Info-Platform (http://cdm.ccchina.gov.cn/zylist.aspx?clmld=162, accessed 26 August 2016). We then assigned project categories, such as 'zero emission renewables', 'biomass', and 'energy efficiency', according to the CDM-equivalent methodologies that are adopted by the project developers. These project categories were directly extracted from the CDM Pipeline's List of Approved Methods (www.cdmpipeline.org). Categories with clear bonding, such as 'Energy efficiency, own generation' and 'Energy efficiency, service', were merged into one group.

A small number of these Chinese methodology codes, notably those of afforestation and reforestation projects, do not have a CDM-equivalent code on the list ${ }^{2}$. Also, some CCER projects are identified with more than one methodology code (mostly under the zero emission renewables and methane avoidance categories). In both cases, project categories were assigned according to project descriptions and titles. Most of the double-coded projects utilize rural biogas and were therefore marked in our sample as 'methane avoidance'. Furthermore, few projects fall into the following categories: fossil fuel switch, PFCs, transport, fugitive emission from fuels, cement, energy distribution, HFCs, and biofuels (fewer than 10 projects each). For simplicity, they were grouped into 'Others' for the purpose of this study.

For comparison, we have also compiled a Chinese CDM database containing information on project location and category. These data were collected from the CDM Pipeline (www.cdmpipeline.org). To ensure consistency, we assigned categories to CDM projects according to the methodologies used.

\footnotetext{
${ }^{2}$ There is one exception, which involves forest carbon sinks in Zhejiang Province and adopts a methodology created on the basis of an approved CDM methodology "Afforestation and reforestation of lands except wetlands") (AR-ACM0003).
} 


\section{Results}

\subsection{Project location}

Figure 1 displays the distribution of the validated CCER projects across China. The majority of these projects are set up in second- and third-tier provinces. As of August 2016, Xinjiang Uyghur Autonomous Region, sitting at the northwestern border of China, has completed 205 project validations and accounts for 8.9 per cent of the national total (Table 3). It is followed by Inner Mongolia in northern China with 160 projects, or 7 per cent. Guizhou, Hubei and Gansu received 5.4, 5.4, and 5.2 per cent of the total, respectively. There are slightly more than 110 validated projects, or around 5 per cent, from Hunan and Yunan, and around 100 projects, or 4.3-4.4 per cent from Shanxi and Jiangsu. Half of the project validations are submitted by the abovementioned nine provinces.

The remaining project validations are recorded in the other 22 provinces and municipalities. About 30 per cent of the second half fall in middle- or lower-income areas, such as Hebei, Henan, Ningxia, Shandong, Guangxi, Sichuan, Qinghai, and Anhui, ranging from 2.8 to 4.2 per cent. The potential market shares of Zhejiang and Guangdong, both of which are wealthy coastal provinces, are 2.8 and 2.3 per cent respective. Heilongjiang and Jilin in the northeastern region have recorded 2 per cent each. The potential market shares of Jiangxi, Fujian, and Liaoning Provinces manage to exceed 1.5 per cent. Few validations are completed in Hainan, an island province in the South, and the four directly administrated municipalities, namely, Beijing, Tianjin, Shanghai and Chongqing, which account for less than 1 per cent each. The Tibet Autonomous Region has recorded only one project validation, putting it at the bottom of the list.

Table 3 compares the number of CCER projects with Chinese CDM projects by province. Xinjiang has seen an increase in offset projects by 4.2 per cent, and Hubei has 3.1 per cent more. Yunan and Sichuan host a large number of Chinese CDM projects (i.e. 9.9 per cent each), but their potential shares of the CCER market are reduced to 4.9 and 3.8 per cent (down by 5 and 6.1 per cent), respectively. Changes in other provinces do not exceed 3 per cent. The differences in geographical distribution are considered to be modest.

Expected annual emission reductions vary significantly across projects, ranging from 546.76 tCO2e (afforestation in Yunan Province) to 5,072,196 tCO2e (hydropower in Sichuan Province). The mean and median values are 108,109 tCO2e and 70,346 tCO2e 
respectively. The variations in output size contribute to a slightly different pattern of geographical distribution (Figure 2). Sichuan, for example, is expected to generate the largest amount of emission reductions (hence, the largest number of CCER credits), i.e. $24,342 \mathrm{ktCO} 2 \mathrm{e}$ across the province, or 9.8 per cent of the national total (Table 4). It is followed by Shanxi $(21,481$ ktCO2e, or 8.7 per cent). Inner Mongolia, Xinjiang, and Guizhou accounted for $7.8,6.6$, and 6.1 per cent, respectively. This puts Gansu, at 5.2 per cent, and Jiangsu, at 4.7 per cent, at the $6^{\text {th }}$ and $7^{\text {th }}$ places. These seven provinces are expected to generate nearly half ( 49 per cent) of the country's aggregate emission reductions under the CCER scheme.

The other 24 provinces and municipalities have committed to the remaining half of the emission reductions. Large provinces, such as Guangdong, Henan, Hebei, and Shangdong, and two northeastern provinces, namely Heilongjiang and Jilin, are found in the middle of the list, all falling within the range of $2.4-4.2$ per cent. Towards the end of the list is a mix of wealthier and poorer areas. For instance, the potential market share (by output size) of Zhejiang, a major coastal province, is comparable with that of Guangxi, an economically deprived Autonomous Region in the country's south, both of which occupy 2.3 per cent of the national total. Jiangxi and Qinghai, both falling below the country's average per capita income level, are only 3 per cent behind the better-off Fujian. Hainan, a small economy in southern China, has committed to producing only 0.3 per cent of the emission reductions from CCER projects, which is a small volume comparable with those of Beijing, China's national capital, and Tianjin. Both Chongqing and Shanghai are megacities with a population of more than 20 million. Despite its much lower GDP per capita, Chongqing has potential market share being only 3 per cent below Shanghai.

The geographical distribution of annual emission reductions from CCER projects is generally similar to that of CDM projects (Table 4). Shanxi and Guizhou have made greater commitment to CCER than CDM, showing an increase in expected reductions by 5.1 and 3.9 per cent respectively. Shandong and Zhejiang fall by 3 and 4.3 per cent, respectively. Changes in other provinces do not exceed 3 per cent. Overall, these variations from the CDM are considered to be modest.

\subsection{Project category}

As shown in Figure 3 and Table 5, most of validated CCER projects (1,502, 65.5 per cent) generate renewable energy from zero-emission sources. The great majority of these projects $(1,489$, or 99.2 per cent) involve wind, hydro, or solar power. The second 
common category is methane avoidance, which can be identified in 378 validated projects, or 16.5 per cent of all. The remaining 18 per cent are divided into five main groups and 'others'. Landfills account for 5.8 per cent. Biomass and afforestation and reforestation take up more than 3 per cent each, while energy efficiency and coal bed / mine methane fall below 2.5 per cent. Other minor categories constitute 0.9 per cent in total. No project application is based on HFCs, biofuels, and $\mathrm{N}_{2} \mathrm{O}$ methodologies (as of August 2016).

Table 5 suggests that the CCER scheme has attracted fewer renewable energy developers from within China than the CDM, which has found 15.6 per cent more "zero emission renewables" projects than the CCER. The decline is nearly offset by the increasing proportion of projects that are designated to avoiding methane emissions, i.e. 13.9 per cent more than those under the CDM. Landfill-based CCER projects have recorded a growth of 4.1 per cent, whereas energy efficiency initiatives have seen a reduction of 4 per cent. Changes in other project categories do not exceed 3 per cent

The full capacity of all validated CCER projects is reducing 248,079 ktCO2e carbon emissions per year. Figure 4 and Table 6 show the amount of expected annual reductions for each project category. Zero emission renewables remain the dominant category, being expected to produce $152,895 \mathrm{ktCO}_{2} \mathrm{e}$ and occupying 61.6 per cent of potential market share. A significant portion of these reductions (over 99 per cent) involves wind, hydro, and solar power. Although there are few coal bed / mine methane projects (2.2 per cent by number), they are likely to become another main source of emission reductions, accounting for $20,674 \mathrm{ktCO}_{2} \mathrm{e}$, or 8.3 per cent of the total. Methane avoidance projects are expected to generate $19,222 \mathrm{ktCO}_{2} \mathrm{e}$ emission reductions, or 7.7 per cent. The remaining 22.3 per cent are distributed among five groups: biomass, energy efficiency, landfill, and afforestation and reforestation have 4 to 6 per cent each, followed by other minor categories with 2.9 per cent.

The expected emission reductions from CCER projects that involve zero emission renewables exceed those from Chinese CDM projects in the same category by a small margin (2.0 per cent) (Table 6). Comparing with the CDM, almost all other major CCER project types have gained a modest percentage increase, ranging from 1.8 per cent (biomass) to 6.5 per cent (methane avoidance). Exceptions include energy efficiency and $\mathrm{N}_{2} \mathrm{O}$-based projects (the latter group is currently absent from the CCER scheme). The largest difference (-14.5 per cent) is observed in the "others" category, which includes HFC and fuel switching projects. Currently, no HFC-based CCER project has completed validation and there are only seven validations recorded for fuel-switching projects, but these two project types account for 91 per cent of expected reductions from the "others" 
category under the $\mathrm{CDM}$, and therefore contribute to this sectoral variation in project output between CCER and CDM.

\section{Discussion and conclusions}

This paper has provided a snapshot of the 'post-CDM' carbon offset market in China through the August 2016. Evidence was sought from the CCER programme, which is a CDM-style domestic carbon pricing mechanism. The study objective was to ascertain whether the CCER programme reveals a general pattern of development that is different from that of the CDM. Official project records were gathered and organized to show the distribution of validated CCER projects across operating locations and their project categories. Despite being broadly consistent with previous studies concerning Chinese CDM projects (Bayer et al., 2013; Thomas et al., 2011), our findings demonstrate nuanced differences.

These differences include, for example, Yunan and Sichuan Provinces not being the largest source of project applications, whereas Xinjiang and Hubei rising to the top. Western, northern, and central areas of China remain popular sites for exploring offsetting opportunities, but a clear trend has yet to emerge. The level of economic development does not seem to be an important predictor. Some of the poorer provinces, such as Guizhou, Gansu, and Yunan, have submitted a relatively large number of project applications, whereas some others, such as Hainan and Jiangxi, have only a handful. A clear observation is that the wealthier ones, notably the four directly administrated municipalities, such as Shanghai and Tianjin, are not particularly active in the offsets industry in terms of the number of project applications. This is largely consistent with the CDM experience in China. Although expected annual emission reductions demonstrate a slightly different pattern of distribution across provinces, due to significant variations in project size, these reductions are concentrated in the western and northern areas of China. The diminishing contributions by provinces in the eastern and northern coasts, namely Zhejiang, Shandong, Jiangsu, Liaoning, which account for nearly 25 per cent of CDM market share in China, are also worth noting.

Based on these observations, we anticipate a larger share of carbon offset credits generated from the inner areas of China than previously produced under the CDM. Examples include Shanxi and Guizhou Provinces, both of which fall below the country's average per capita income level. A potential implication of this emerging configuration is that these inner areas might experience an accelerated structural transformation as a result of the CCER programme. For instance, Shanxi is the largest 
source of coal in China. Through the CCER market, coal producers in this province are likely to have greater access to finance and technology that are crucial for supporting a strategic transition to renewable energy development, given that the central government of China has decided to peak its carbon emissions by 2030 (Xinhua News Agency, 2014). Furthermore, producing carbon offset credits from inner areas can generate development benefits. Guizhou is essentially a rural economy; it is expected to produce a much larger share (27 per cent) of emission reductions from methane avoidance (predominantly from the reuse of biogas by rural households) than the national average ( 7.7 per cent). Households who struggle to maintain their livelihood can benefit from the lower energy costs and an alternative source of revenue arising from these biogas projects. If this pattern of distribution continues to develop, the CCER programme might be able to accelerate the structural transformation and support development in these and other inner provinces in China's north and west.

Most of the Chinese CDM projects are based on renewable energy, especially wind power and hydroelectricity. Renewable energy remains an important sector in the CCER market. Comparing with the CDM, the CCER project validation records indicate an increase in efforts on reducing methane emissions, mostly from small-scale rural sources. Opportunities for reducing emissions from municipal waste treatment processes (landfill) and tree planting (afforestation and reforestation) are also emerging. It should be noted that the number of registered CDM projects that are based on afforestation and reforestation methodologies has been negligible (about 0.1 per cent for China alone) (UNEP DTU Partnership, 2016). Removal or avoidance of industrial gases, notably HFCs, PFCs and $\mathrm{N}_{2} \mathrm{O}$, is close to non-existence in the CCER project validation records.

The sectoral distribution of expected emission reductions substantially differs from that of the number of projects, due to variations in individual project outputs. Mitigation of HFC and $\mathrm{N}_{2} \mathrm{O}$ emissions and fossil fuel switch offer lower-cost opportunities for controlling GHG emissions. Among the 3,512 Chinese CDM projects in our records, only eighty of them ( 2.3 per cent) are based on these methodologies, but they contribute to 20.5 per cent of the total emission reductions. Despite their costeffectiveness, these projects are under-represented in the CCER programme. Hydropower and wind power are relatively cheaper forms of renewable energy in China (Teng and Zhang, 2010). Although the expected emission reductions from renewable energy have increased (by a small margin, i.e. 2 per cent), the number of these projects has showed a sharp decline (15.6 per cent). These less costly options have not strengthened their presence in the CCER market. 
On the other hand, methane avoidance has become an attractive option in CCER development. It typically involves small-scale project: the annual emission reductions of the 378 CCER projects based on methane avoidance averaged 50.9 ktCO2e only, far below the other categories listed in Table 6, which range from 102 to $413 \mathrm{ktCO} e$ on average. Mostly located in rural communities, these small-scale attempts require close monitoring at numerous dispersed spots that capture volatile gases, raising concerns about cost-effectiveness. Further research is needed to evaluate the extent to which the CCER programme has provided cost-effective options for GHG mitigation in China.

This early review of progress has presented a broad picture of the emerging project-based carbon market in China. It indicates a modest degree of departure from the CDM in China, which nonetheless warrant regular monitoring and review. At present, the state-led CCER programme is on a pathway that is similar to the CDM in China in terms of geographical distribution. The western and northern areas will continue to play a key role, if not a stronger one, as the market infrastructure becomes mature and local practitioners gain experience. The potential benefits for regional and local economies will be an important issue to explore in evaluating the success of CCER at the economy level. Moreover, the majority of offset credits are likely to be derived from renewable energy sources, while a significant minority come from waste-based ones. Sectoral distribution is a potential source of variations from the CDM, which may bring up a series of questions about the project-level success of CCER in mitigating GHG emissions at lower costs.

Our findings inevitably remain preliminary, and further research is necessary as projects unfold and more information is released by the Chinese government in the next few years. Nevertheless, the initial observations allow market participants, new energy developers and researchers to forecast the potential market share of key provinces and sectors. Similar efforts will be needed to explore the CCER registration database as public records accumulate.

\section{Acknowledgements}

This research received financial support from the Early Career Scheme of the Regional Studies Association and the HKU Hui Oi Trust Fund - General Award. 
Table 1 GDP and population of Chinese provinces in 2014

\begin{tabular}{|c|c|c|c|}
\hline & $\begin{array}{l}\text { GDP (billion } \\
\text { USD) }\end{array}$ & $\begin{array}{c}\text { Population } \\
\text { (million) }\end{array}$ & $\begin{array}{l}\text { GDP per capita } \\
\text { (thousand USD) }\end{array}$ \\
\hline Tianjin & 253.5 & 15.2 & 16.7 \\
\hline Beijing & 343.8 & 21.5 & 16.0 \\
\hline Shanghai & 379.8 & 24.3 & 15.7 \\
\hline Jiangsu & $1,049.0$ & 79.6 & 13.2 \\
\hline Zhejiang & 647.5 & 55.1 & 11.8 \\
\hline Inner Mongolia & 286.4 & 25.1 & 11.4 \\
\hline Liaoning & 461.4 & 43.9 & 10.5 \\
\hline Guangdong & $1,092.9$ & 107.2 & 10.2 \\
\hline Fujian & 387.7 & 38.1 & 10.2 \\
\hline Shandong & 957.8 & 97.9 & 9.8 \\
\hline Jilin & 222.5 & 27.5 & 8.1 \\
\hline Chongqing & 229.9 & 29.9 & 7.7 \\
\hline Hubei & 441.3 & 58.2 & 7.6 \\
\hline Shaanxi & 285.1 & 37.8 & 7.6 \\
\hline Ningxia & 44.4 & 6.6 & 6.7 \\
\hline Xinjiang & 149.5 & 23.0 & 6.5 \\
\hline Hunan & 435.8 & 67.4 & 6.5 \\
\hline Hebei & 474.2 & 73.8 & 6.4 \\
\hline Qinghai & 37.1 & 5.8 & 6.4 \\
\hline Heilongjiang & 242.4 & 38.3 & 6.3 \\
\hline Hainan & 56.4 & 9.0 & 6.2 \\
\hline Henan & 563.1 & 94.4 & 6.0 \\
\hline Sichuan & 459.9 & 81.4 & 5.7 \\
\hline
\end{tabular}




\begin{tabular}{|c|c|c|c|}
\hline Shanxi & 205.7 & 36.5 & 5.6 \\
\hline Jiangxi & 253.3 & 45.4 & 5.6 \\
\hline Anhui & 336.0 & 60.8 & 5.5 \\
\hline Guangxi & 252.6 & 47.5 & 5.3 \\
\hline Tibet & 14.8 & 3.2 & 4.7 \\
\hline Yunan & 206.5 & 47.1 & 4.4 \\
\hline Guizhou & 149.3 & 35.1 & 4.3 \\
\hline Gansu & 110.2 & 25.9 & 4.3 \\
\hline People’s Republic of China & $11,029.7$ & $1,362.5$ & 8.1 \\
\hline
\end{tabular}


Table 2 Carbon prices and trading volumes in the Chinese carbon markets

\begin{tabular}{|c|c|c|c|c|c|}
\hline \multirow[t]{2}{*}{ Location } & \multicolumn{2}{|c|}{ Emissions allowance (ETS) } & \multicolumn{3}{|c|}{ Chinese Certified Emission Reduction (CCER) } \\
\hline & $\begin{array}{l}\text { Accumulated } \\
\text { trading } \\
\text { volume } \\
\left(\mathrm{MtCO}_{2} \mathrm{e}\right)^{*}\end{array}$ & $\begin{array}{l}\text { Average price / } \\
\mathrm{tCO}_{2} \mathrm{e}(\mathrm{US} \$)^{\wedge}\end{array}$ & $\begin{array}{l}\text { Accumulat } \\
\text { ed trading } \\
\text { volume } \\
\left(\mathrm{MtCO}_{2} \mathrm{e}\right)^{\#}\end{array}$ & $\begin{array}{l}\text { Average } \\
\text { price / } \\
\text { tCO2e } \\
\text { (US\$) }^{\wedge \#}\end{array}$ & $\begin{array}{l}\text { Maximum allowable } \\
\text { use of CCER in pilot } \\
\text { ETS (\% of local } \\
\text { emission caps) }\end{array}$ \\
\hline Beijing & 11.7 & 5.7 & 8.6 & 2.5 & 5 \\
\hline Tianjin & 2.4 & 2.5 & 1.3 & - & 10 \\
\hline Shanghai & 16.2 & 1.7 & 36.7 & 3.7 & 5 \\
\hline Chongqing & 0.4 & 2.7 & - & - & 8 \\
\hline Shenzhen & 16.0 & 5.2 & 5.6 & - & 10 \\
\hline Guangdong & 35.8 & 4.7 & 14.9 & - & 10 \\
\hline Hubei & 35.6 & 3.2 & 1.6 & - & 10 \\
\hline Total & 118.1 & 4.0 & 68.7 & - & - \\
\hline
\end{tabular}

Sources:

Zhang (2015a) (for the allowable use of CCER in pilot ETS).

China Beijing Environment Exchange Weekly Express 2016 No.33 (www.cbeex.com.cn) (for the CCER price in Beijing)

Shanghai Environment and Carbon Exchange Carbon Market Express, Vol.134, August 2016, and Vol. 131, July 2016 (www.cneeex.com) (for all other information).

Notes:

* From launch dates to 19 August 2016.

${ }^{\wedge}$ Average prices originally in Chinese yuan were converted to USD at the rate of 6.6515 based on the Federal Reverse's exchange rate records (19 August 2016)

\# data are only available in selected locations 
Figure 1 Number of validated CCER projects by province

(see attachment)

Source: China Certified Emission Reduction Exchange Info-Platform

(http://cdm.cchina.gov.cn/ccer.aspx). Accessed 9 August 2016. 
Figure 2 Expected annual emission reductions by province

(see attachment)

Source: China Certified Emission Reduction Exchange Info-Platform

(http://cdm.ccchina.gov.cn/ccer.aspx). Accessed 9 August 2016. 
Figure 3 Number of CCER projects by project category (through 9 August 2016)

\section{Validated CCER projects (total $=2,294$ )}

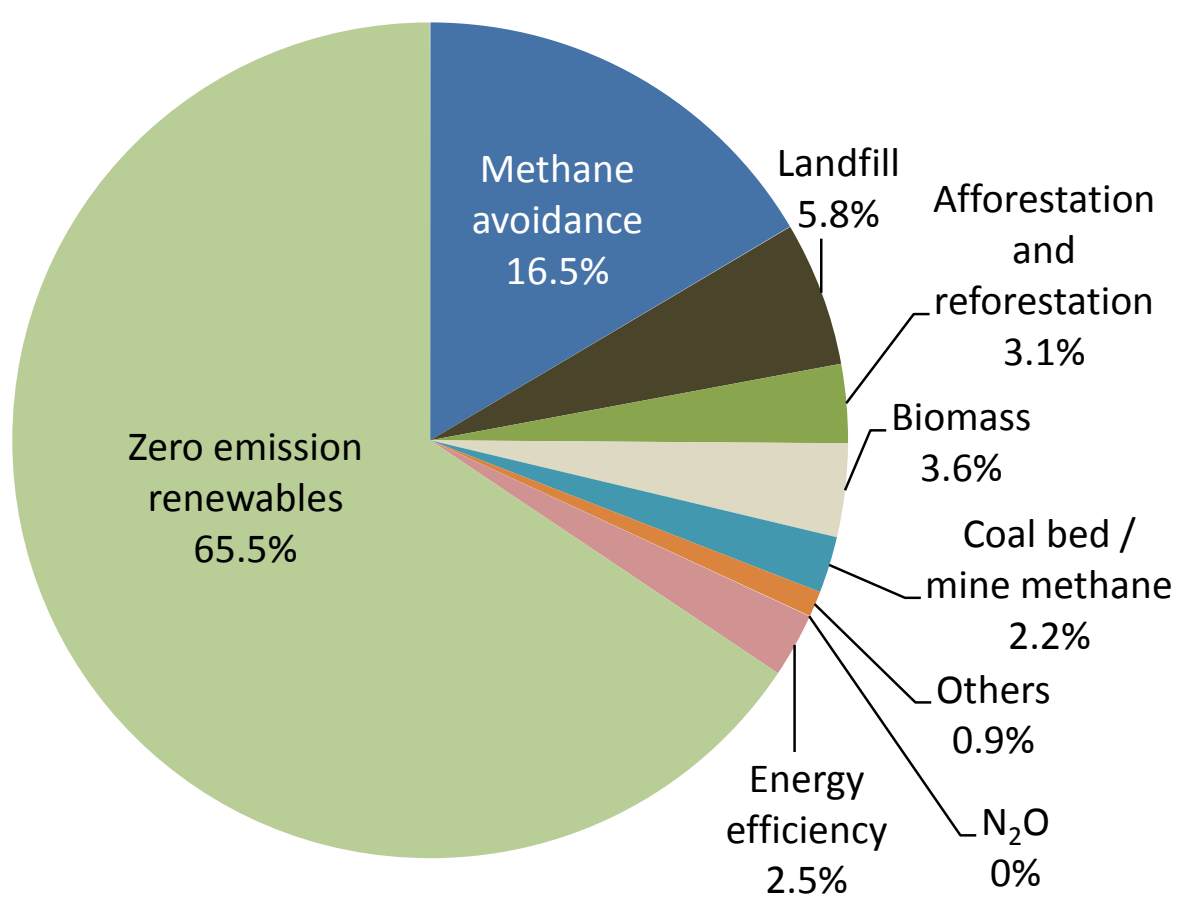

Source: China Certified Emission Reduction Exchange Info-Platform (http://cdm.cchina.gov.cn/ccer.aspx). Accessed 9 August 2016. 
Figure 4 Expected annual emission reductions during the first crediting period $\left(\mathrm{ktCO}_{2} \mathrm{e}\right)$ by project type (through 9 August 2016)

\section{Validated CCER projects (total $=248,079 \mathrm{ktCO2e}$ )}

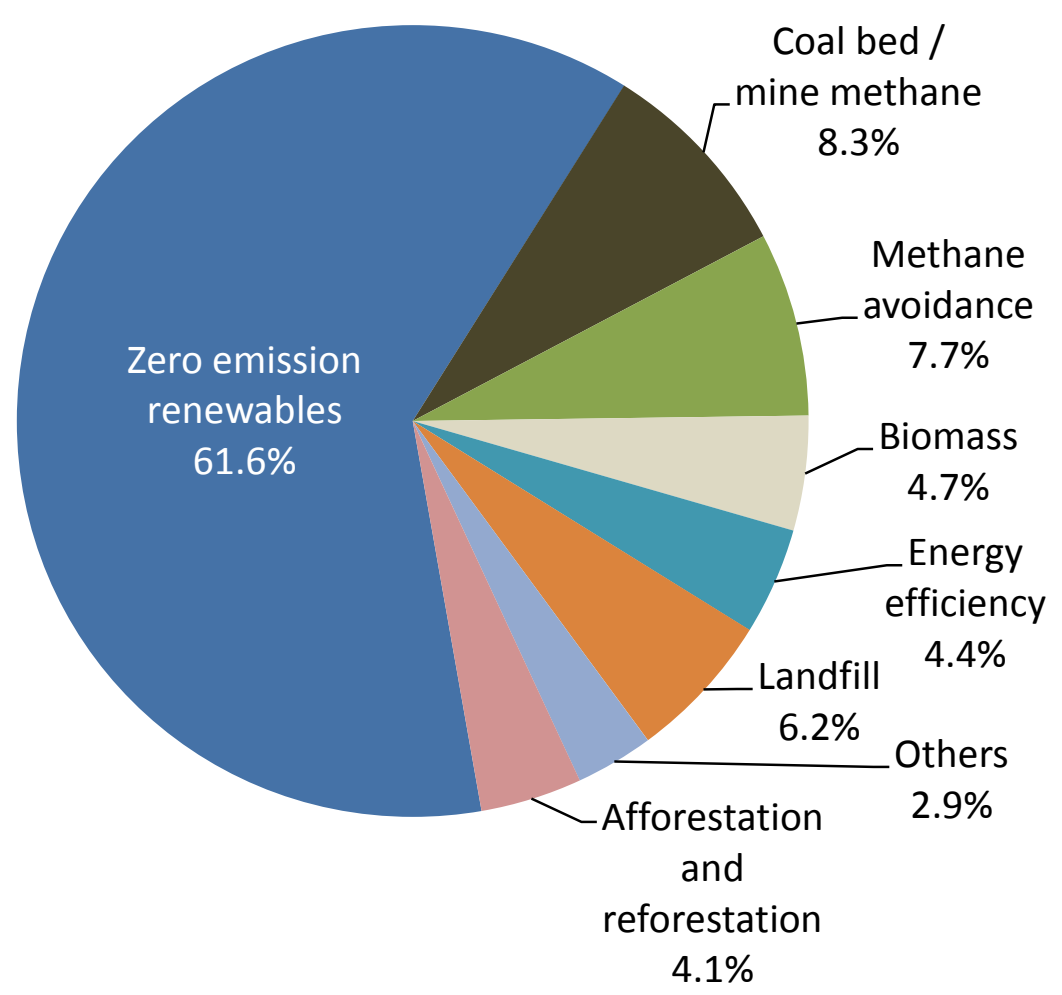

Source: China Certified Emission Reduction Exchange Info-Platform (http://cdm.cchina.gov.cn/ccer.aspx). Accessed 9 August 2016. 


\begin{tabular}{|c|c|c|c|}
\hline Province & $\begin{array}{c}\text { Number of } \\
\text { validated CCER } \\
\text { projects (\%) }\end{array}$ & $\begin{array}{c}\text { Number of } \\
\text { registered CDM } \\
\text { projects (\%) }\end{array}$ & $\begin{array}{c}\text { Difference in } \\
\text { percentage } \\
(\%)\end{array}$ \\
\hline Xinjiang & 205 (8.9) & $168(4.8)$ & 4.2 \\
\hline Inner Mongolia & $160(7.0)$ & 323 (9.2) & -2.2 \\
\hline Guizhou & $125(5.4)$ & $96(2.7)$ & 2.7 \\
\hline Hubei & $125(5.4)$ & $84(2.4)$ & 3.1 \\
\hline Gansu & $119(5.2)$ & $228(6.5)$ & -1.3 \\
\hline Hunan & $115(5.0)$ & 138 (3.9) & 1.1 \\
\hline Yunan & $113(4.9)$ & 347 (9.9) & -5.0 \\
\hline Shanxi & $102(4.4)$ & $83(2.4)$ & 2.1 \\
\hline Jiangsu & 98 (4.3) & $70(2.0)$ & 2.3 \\
\hline Hebei & $96(4.2)$ & $175(5.0)$ & -0.8 \\
\hline Henan & $93(4.1)$ & $78(2.2)$ & 1.8 \\
\hline Ningxia & $92(4.0)$ & $147(4.2)$ & -0.2 \\
\hline Shandong & $92(4.0)$ & $181(5.2)$ & -1.1 \\
\hline Guangxi & $91(4.0)$ & $76(2.2)$ & 1.8 \\
\hline Sichuan & 87 (3.8) & 346 (9.9) & -6.1 \\
\hline Qinghai & $68(3.0)$ & 56 (1.6) & 1.4 \\
\hline Anhui & 65 (2.8) & 57 (1.6) & 1.2 \\
\hline Zhejiang & 65 (2.8) & 65 (1.9) & 1.0 \\
\hline Guangdong & $52(2.3)$ & $81(2.3)$ & 0.0 \\
\hline Shaanxi & $50(2.2)$ & $124(3.5)$ & -1.4 \\
\hline Heilongjiang & $46(2.0)$ & $108(3.1)$ & -1.1 \\
\hline Jilin & $46(2.0)$ & 115 (3.3) & -1.3 \\
\hline
\end{tabular}




\begin{tabular}{lrrr} 
Jiangxi & $41(1.8)$ & $50(1.4)$ & 0.4 \\
Fujian & $40(1.7)$ & $85(2.4)$ & -0.7 \\
Liaoning & $39(1.7)$ & $123(3.5)$ & -1.8 \\
Beijing & $16(0.7)$ & $17(0.5)$ & 0.2 \\
Chongqing & $15(0.7)$ & $50(1.4)$ & -0.8 \\
Hainan & $15(0.7)$ & $17(0.5)$ & 0.2 \\
Shanghai & $15(0.7)$ & $15(0.4)$ & 0.2 \\
Tianjin & $7(0.3)$ & $9(0.3)$ & 0.0 \\
Tibet & $1(0.0)$ & $0(0.0)$ & 0.0 \\
Total & $2,294(100)$ & $3,512(100)$ & - \\
\hline
\end{tabular}

Note: Ranked by the number of CCER projects. A total of 252 CDM projects were excluded because of duplication with CCER records.

Source: China Certified Emission Reduction Exchange Info-Platform

(http://cdm.ccchina.gov.cn/ccer.aspx). Accessed 9 August 2016. 
Table 4 Expected annual emission reductions from CCER and CDM projects during the first crediting period (through 9 August 2016)

\begin{tabular}{|c|c|c|c|}
\hline Province & $\begin{array}{c}\text { Expected annual } \\
\text { emission reductions } \\
\text { from validated CCER } \\
\text { projects }\left(\mathrm{ktCO}_{2} \mathrm{e}\right)(\%)\end{array}$ & $\begin{array}{c}\text { Expected annual } \\
\text { emission reductions } \\
\text { from registered } \mathrm{CDM} \\
\text { Projects }\left(\mathrm{ktCO}_{2} \mathrm{e}\right)(\%)\end{array}$ & $\begin{array}{c}\text { Difference in } \\
\text { percentage } \\
(\%)\end{array}$ \\
\hline Sichuan & $24,342(9.8)$ & 62,357 (11.6) & -1.7 \\
\hline Shanxi & $21,481(8.7)$ & 19,293 (3.6) & 5.1 \\
\hline Inner Mongolia & 19,298 (7.8) & $45,172(8.4)$ & -0.6 \\
\hline Xinjiang & 16,463 (6.6) & $26,422(4.9)$ & 1.7 \\
\hline Guizhou & 15,217 (6.1) & 11,949 (2.2) & 3.9 \\
\hline Gansu & 13,005 (5.2) & $26,823(5.0)$ & 0.3 \\
\hline Jiangsu & 11,675 (4.7) & $32,434(6.0)$ & -1.3 \\
\hline Hebei & $10,314(4.2)$ & 22,261 (4.1) & 0.0 \\
\hline Hunan & $10,296(4.2)$ & 12,486 (2.3) & 1.8 \\
\hline Yunan & $9,833(4.0)$ & 37,216 (6.9) & -2.9 \\
\hline Ningxia & 8,395 (3.4) & 12,729 (2.4) & 1.0 \\
\hline Hubei & 8,228 (3.3) & 10,048 (1.9) & 1.5 \\
\hline Shandong & 7,949 (3.2) & $33,470(6.2)$ & -3.0 \\
\hline Jilin & 7,326 (3.0) & $12,858(2.4)$ & 0.6 \\
\hline Heilongjiang & 7,035 (2.8) & 15,133 (2.8) & 0.0 \\
\hline Henan & 6,865 (2.8) & $13,744(2.5)$ & 0.2 \\
\hline Guangdong & $5,936(2.4)$ & $13,371(2.5)$ & -0.1 \\
\hline Zhejiang & $5,751(2.3)$ & 35,613 (6.6) & -4.3 \\
\hline Guangxi & 5,718 (2.3) & 9,598 (1.8) & 0.5 \\
\hline Liaoning & $5,579(2.2)$ & $27,038(5.0)$ & -2.8 \\
\hline Shaanxi & $5,296(2.1)$ & 15,436 (2.9) & -0.7 \\
\hline
\end{tabular}




\begin{tabular}{lrrr} 
Anhui & $4,880(2.0)$ & $6,675(1.2)$ & 0.7 \\
Fujian & $3,976(1.6)$ & $11,870(2.2)$ & -0.6 \\
Jiangxi & $3,238(1.3)$ & $4,579(0.8)$ & 0.5 \\
Qinghai & $3,223(1.3)$ & $4,049(0.8)$ & 0.5 \\
Shanghai & $2,597(1.0)$ & $3,063(0.6)$ & 0.5 \\
Chongqing & $1,724(0.7)$ & $7,487(1.4)$ & -0.7 \\
Beijing & $1,336(0.5)$ & $4,925(0.9)$ & -0.4 \\
Hainan & $816(0.3)$ & $888(0.2)$ & 0.2 \\
Tianjin & $222(0.1)$ & $766(0.1)$ & -0.1 \\
Tibet & $63(0.0)$ & $0(0.0)$ & 0.0 \\
\multicolumn{1}{c}{ Total } & $248,079(100)$ & $539,753(100)$ & - \\
\hline
\end{tabular}

Note: Ranked by the volume of expected reductions from CCER projects. The national total is slightly higher than the sum of provincial totals due to rounding-up.

Source: China Certified Emission Reduction Exchange Info-Platform (http://cdm.cchina.gov.cn/ccer.aspx). Accessed 9 August 2016. 
Table 5Number of CCER and CDM projects (through 9 August 2016)

\begin{tabular}{lrrr}
\multicolumn{1}{c}{ Project category } & $\begin{array}{c}\text { (a) Number of } \\
\text { validated CCER } \\
\text { projects (\%) }\end{array}$ & $\begin{array}{c}\text { (b) Number of } \\
\text { registered CDM } \\
\text { projects (\%) }\end{array}$ & $\begin{array}{c}\text { Difference in } \\
\text { percentage (a } \\
\text { - b) (\%) }\end{array}$ \\
\hline Zero emission renewables & $1,502(65.5)$ & $2,848(81.1)$ & -15.6 \\
Methane avoidance & $378(16.5)$ & $90(2.6)$ & 13.9 \\
Landfill & $133(5.8)$ & $59(1.7)$ & 0.6 \\
Biomass & $83(3.6)$ & $106(3.0)$ & 2.9 \\
Afforestation and & $70(3.1)$ & $5(0.1)$ & -4.0 \\
reforestation & & $226(6.4)$ & 0.2 \\
Energy efficiency & $57(2.5)$ & $71(2.0)$ & -1.3 \\
Coal bed / mine methane & $50(2.2)$ & $47(1.3)$ & -0.8 \\
$\mathrm{~N}_{2} \mathrm{O}$ & $0(0.0)$ & $60(1.7)$ & - \\
Others & $21(0.9)$ & $3,512(100)$ & \\
\hline \multicolumn{1}{l}{ Total } & $2,294(100)$ & & \\
\hline
\end{tabular}

Note: Ranked by the number of CCER projects. A total of 252 CDM projects were excluded because of duplication with CCER records. "Others" include fossil fuel switch, PFCs, transport, fugitive emission from fuels, cement, energy distribution, HFCs, and biofuels.

Source: China Certified Emission Reduction Exchange Info-Platform (http://cdm.ccchina.gov.cn/ccer.aspx). Accessed 9 August 2016. 
Table 6 Expected annual emission reductions from CCER and CDM projects during the first crediting period (through 9 August 2016)

\begin{tabular}{|c|c|c|c|}
\hline Project category & $\begin{array}{l}\text { (a) Expected annual } \\
\text { emission reductions } \\
\text { from validated CCER } \\
\text { projects }\left(\mathrm{ktCO}_{2} \mathrm{e}\right)(\%)\end{array}$ & $\begin{array}{l}\text { (b) Expected annual } \\
\text { emission reductions } \\
\text { from registered CDM } \\
\text { Projects }\left(\mathrm{ktCO}_{2} \mathrm{e}\right)(\%)\end{array}$ & $\begin{array}{l}\text { Difference in } \\
\text { percentage (a } \\
\quad-\mathbf{b})(\%)\end{array}$ \\
\hline $\begin{array}{l}\text { Zero emission } \\
\text { renewables }\end{array}$ & $152,895(61.6)$ & 321,904 (59.6) & 2.0 \\
\hline $\begin{array}{l}\text { Coal bed / mine } \\
\text { methane }\end{array}$ & $20,674(8.3)$ & $27,601(5.1)$ & 3.2 \\
\hline Methane avoidance & $19,222(7.7)$ & 6,767 (1.3) & 6.5 \\
\hline Landfill & $15,320(6.2)$ & 7,148 (1.3) & 4.9 \\
\hline Biomass & $11,604(4.7)$ & $15,310(2.8)$ & 1.8 \\
\hline Energy efficiency & $10,832(4.4)$ & 41,832 (7.8) & -3.4 \\
\hline $\begin{array}{l}\text { Afforestation and } \\
\text { reforestation }\end{array}$ & $10,272(4.1)$ & $183(0.0)$ & 4.1 \\
\hline $\mathrm{N}_{2} \mathrm{O}$ & $0(0.0)$ & 24,806 (4.6) & -4.6 \\
\hline Others & 7,259 (2.9) & $94,201(17.5)$ & -14.5 \\
\hline Total & $248,079(100)$ & 539,753 (100) & - \\
\hline \multicolumn{4}{|c|}{$\begin{array}{l}\text { Note: Ranked by the volume of expected reductions from CCER projects. "Others" include fossil } \\
\text { fuel switch, PFCs, transport, fugitive emission from fuels, cement, energy distribution, HFCs, and } \\
\text { biofuels. }\end{array}$} \\
\hline
\end{tabular}




\section{References:}

Bayer, P., Urpelainen, J., Wallace, J., 2013. Who uses the Clean Development Mechanism? An empirical analysis of projects in Chinese provinces. Global Environmental Change 23, 512-521.

Buhr, K., Thörn, P., Hjerpe, M., 2012. The Clean Development Mechanism in China: Institutional Perspectives on Governance. Environmental Policy and Governance 22, 77-89.

Lo, A.Y., 2015. National development and carbon trading: the symbolism of Chinese climate capitalism. Eurasian Geography and Economics 56, 111-126.

Lo, A.Y., Howes, M., 2013. Powered by the state or finance? The organization of China's carbon markets. Eurasian Geography and Economics 54, 386-408.

Lo, A.Y., Howes, M., 2015. Power and Carbon Sovereignty of a Non-Traditional Capitalist State: The Carbon Trading Discourse of China. Global Environmental Politics 15, 60-82.

National Development and Reform Commission, 2012. Interim Measures for the Administration of Voluntary Greenhouse Gas Emission Reduction Trading. No. 1668 [2012]. . National Development and Reform Commission, Beijing.

Schröder, M., 2011. Local Climate Governance in China. Palgrave Macmillan, Basingstoke, p. 248.

Shanghai Environment and Carbon Exchange, 2016. Carbon Market Express. January 2016, vol. 104 (available from www.cneeex.com. accessed 25 February 2016) [In Chinese].

Shen, W., 2015. Chinese business at the dawn of its domestic emissions trading scheme: incentives and barriers to participation in carbon trading. Climate Policy 15, 339-354.

Teng, F., Zhang, X., 2010. Clean development mechanism practice in China: Current status and possibilities for future regime. Energy 35, 4328-4335.

Thomas, S., Dargusch, P., Griffiths, A., 2011. The Drivers and Outcomes of the Clean Development Mechanism in China. Environmental Policy and Governance 21, 223-239.

UNEP DTU Partnership, 2016. CDM/JI Pipeline Analysis and Database (accessed 1 Feb 2016). UNEP DTU Partnership, Copenhagen.

Wang, Q., Chen, Y., 2010. Barriers and opportunities of using the clean development mechanism to advance renewable energy development in China. Renewable and Sustainable Energy Reviews 14, 1989-1998.

World Bank, 2015. State and Trends of Carbon Pricing 2015. World Bank Group, Washington, D.C.

Wu, L., Qian, H., Li, J., 2014. Advancing the experiment to reality: Perspectives on Shanghai pilot carbon emissions trading scheme. Energy Policy 75, 22-30.

Xinhua News Agency, 2014. China-US Joint Announcement on Climate Change, Xinhua News, Beijing. Accessed 6 September 2016. Available at http://www.gov.cn/xinwen/201411/13/content 2777663.htm.

Zhang, Z., 2015a. Carbon emissions trading in China: the evolution from pilots to a nationwide scheme. Climate Policy 15, S104-S126.

Zhang, Z., 2015b. Crossing the river by feeling the stones: the case of carbon trading in China. Environ Econ Policy Stud 17, 263-297. 